\title{
Phytoplankton responses to meteorological and hydrological forcing at decadal to seasonal time scales
}

\author{
Nasime Janatian (D) Kalle Olli $\cdot$ Peeter Nõges
}

Received: 3 August 2020/Revised: 16 March 2021/Accepted: 16 April 2021/Published online: 30 April 2021

(C) The Author(s) 2021

\begin{abstract}
One of the challenges for predicting global change effects on aquatic ecosystems is the vague understanding of the mechanisms of multiple controlling factors affecting phytoplankton dynamics at different time scales. Here we distinguish between hydrometeorological forcing of phytoplankton dynamics at time scales from days to decades based on a 54-year monthly phytoplankton time series from a large shallow Lake Võrtsjärv $\left(58^{\circ} 16^{\prime} \mathrm{N}, 26^{\circ} 02^{\prime} \mathrm{E}\right)$ in Estonia, combined with daily data on forcing factorsthermal-, wind-, light- and water-level regimes. By using variance partitioning with linear mixed effect modelling (LME), we found a continuum from the large dominant K-selected filamentous cyanobacteria
\end{abstract}

Handling editor: Judit Padisák

Supplementary Information The online version of this article (https://doi.org/10.1007/s10750-021-04594-x) contains supplementary material, which is available to authorised users.

N. Janatian $(\varangle) \cdot$ K. Olli $\cdot$ P. Nõges

Chair of Hydrobiology and Fishery, Estonian University

of Life Sciences, Tartu, Estonia

e-mail: n.janatian@emu.ee

N. Janatian

Department of Evolutionary Biology, Ecology and Environmental Sciences, University of Barcelona, Barcelona, Spain

K. Olli

Institute of Ecology and Earth Sciences, University of Tartu, Tartu, Estonia with strongest decadal scale variation (8-30\%) to r-selected phytoflagellates with large stochastic variability (80-96\%). External forcing revealed strong seasonal variation (up to $80 \%$ ), while specifically water level and wind speed had a robust decadal variation ( $8 \%$ and $20 \%$, respectively). The effect of external variables was proportionally manifested in the time scales of phytoplankton variation. Temperature, with a clear seasonal variation, had no impact on the dominant cold tolerant filamentous cyanobacteria in Lake Võrtsjärv. We found the LME as a reliable method for resolving the temporal cross-scale problem. It yielded quantitative results that matched our intuitive understanding of the dynamics of different variables.

Keywords Phytoplankton dynamics $\cdot$ Large shallow lake Long-term data Variance partitioning $\cdot$ Time scale $\cdot$ Lake Võrtsjärv

\section{Introduction}

Phytoplankton is contributing about half of the global organic matter production (Field, 1998) and forms the basis of most aquatic food webs. Despite advances in phytoplankton ecology on the effects of both abiotic (e.g. Cuypers et al., 2011; Posch et al., 2012; Durham et al., 2013) and biotic factors (e.g. Eiler et al., 2012; 
Hansson et al., 2012; Edwards et al., 2013; Amin et al., 2015; Shatwell et al., 2016), the mechanisms controlling phytoplankton community composition and dynamics remain poorly understood. A source of uncertainty in phytoplankton models is the poorly resolved multiscalarity issue arising from the weak coupling between atmosphere/aquatic physics and biological responses across time and space scales (Francis et al., 1998). A number of studies have been dedicated to temporal dynamics of phytoplankton at time scales from diurnal to geological, but there is little understanding of cross-scale patterns ( $\mathrm{Li}$ et al., 2010; Thomas et al., 2018). Thomas et al. (2018) comparing the predictability of phytoplankton development based on high frequency ( $4 \mathrm{~h}$ ) to decadal scale biological, physical and chemical monitoring data from a Swiss lake found the cell densities to be highly predictable over hours to months, whereas the predictability dropped at longer time scales.

Phytoplankton species represent different life strategies and being variously adapted to changes in the environment perceive disturbances differently. Short-term responses of phytoplankton to stochastic disturbances are likely to constitute a large part of the total variability in phytoplankton (recently reviewed in Stockwell et al., 2020). A wind event, for example, may disrupt a cyanobacteria surface bloom (Wu et al., 2013), but gives advantage to diatoms that need higher turbulence (Fraisse et al., 2015) or green algae by creating a nutrient pulse through deeper mixing (Carrick et al., 1993). On a time scale of a few days, wind events can modify phytoplankton dynamics favouring the largest size classes and inhibiting the smallest size classes, while an increase in stratification has the opposite effects (Pannard et al., 2007). Further, after short-term wind forcing, the phytoplankton community may take a different track and not return to its original structure because of modifications of the resource availability or stratification intensity (Pannard et al., 2008).

Seasonal course of light and temperature and the resulting changes in resource availability mediated by the food chain causes lake-type-specific succession of phytoplankton community repeating in a rather predictable way from year to year (Sommer et al., 2012). Year-to-year changes in phytoplankton are tightly connected to seasonal changes, notably with anomalies in seasonality and phenology. For instance, different initial conditions of seasonal cycles in temperate lakes - the timing of ice breakup, the height of spring peak in water levels, timing, duration, and extent of spring overturn-lead the system to pursue various trajectories in their seasonal succession. The effect of initial conditions is often extended to later parts of the season through match and mismatch processes in the food web (Winder \& Schindler, 2004; Thackeray et al., 2013a).

On top of anthropogenic eutrophication and nutrient loading, decadal to centennial-scale changes in lake ecosystems are most often linked to climatic forcing (Adrian et al., 2009) and changes in catchment land use, whereas the effects of these factors are often difficult to disentangle (Moss et al., 2011). Interannual to decadal phytoplankton fluctuations strongly correlate with atmospheric circulation patterns such as the North Atlantic Oscillation (NAO) and El NiñoSouthern Oscillation (ENSO) that are often superimposed on long-term warming trends (Gerten \& Adrian, 2002). Aside from the gradual changes in phytoplankton composition and abundance, environmental forcing may cause lake systems to exceed their resilience and exhibit regime shifts, i.e. transitions between alternative and substantially different stable states (Scheffer \& van Nes, 2007).

In this study, we analyse phytoplankton temporal response scales (decadal, annual, seasonal, and daily) to external forcing. Here we focus on hydrometeorological variables, with total nitrogen (TN) and total phosphorus (TP) concentrations included to provide consistency with previous studies (Nõges et al., 2003, 2010; Pall et al., 2011). We use a variance partitioning scheme and a correlative analysis to study the relative importance at which different time scales of the external forcing variables act on various phytoplankton groupings.

As hydrometeorological forcing factors, we included water level (WL), surface water temperature (SWT), photosynthetically active radiation in the mixed layer (PARmix) and wind speed (U). Due to large fluctuations, WL is the pivotal environmental factor in Võrtsjärv, reflecting the general water richness, catchment loadings of nutrients and organic matter (Nõges \& Järvet, 1995; Nõges \& Nõges, 1998; Nõges et al., 2003). In Võrtsjärv water level affects phytoplankton through variable strength of sediment resuspension, the release of nutrients, water turbidity and underwater light climate. Summer water temperature in Võrtsjärv increased on average $0.28^{\circ} \mathrm{C}$ per 
decade over the 50 years from 1961 to 2011 (Nõges \& Nõges, 2014) with likely implications on phytoplankton physiology (Wagner et al., 2016) and food chain relationships (Vasconcelos et al., 2019).

External nutrient loading to the lake was highest during the 1970s and 1980s, reflecting poor agricultural practices (Pall et al., 2011). The nutrient loading and in-lake concentrations have decreased since 1980s, yet the phytoplankton-inferred water quality has not improved (Nõges et al., 2010). Phytoplankton in Võrtsjärv is strongly light limited and an increase in phytoplankton biomass has been promoted by improved underwater light climate due to reduced amount of suspended sediments followed by a significant wind stilling since 1997 (Janatian et al., 2019). For this reason, we included in the analysis PAR in the mixed layer and wind speed.

We hypothesise that the effect of hydrometeorological forcing variables on phytoplankton at different time scales follows proportionally the variance partitioning of these explanatory variables. Variance partitioning could provide a useful method for disentangling several of the multi-timescale problems. For example, unravelling the cross-scale temporal response of phytoplankton to meteorological and hydrological forcing corroborates successful biomanipulation and water management (Benndorf et al., 2002).

We expect to see water-level effects mostly at a seasonal or multi-annual scale, temperature effects at a seasonal scale and wind effects at a shorter time scale. Phytoplankton responses to wind events reveal immediate effects of growth limiting factors such as nutrients or light. In contrast, at longer time scales, the relationships may be mediated by other factors like food-web relations and contain time lags. Ultimately, at the decadal scale, wind forcing may overhaul the phytoplankton community structure, as shown by Janatian et al. (2019). Hence, the time scale of appearing an effect bears important information on the kind of the relationship.

\section{Materials and methods}

Site description

Lake Võrtsjärv is a large (area $270 \mathrm{~km}^{2}$ ), shallow (mean depth $2.8 \mathrm{~m}$, maximum $6 \mathrm{~m}$ ) eutrophic lake located in the central part of Estonia $\left(58^{\circ} 16^{\prime} \mathrm{N}\right.$, $\left.26^{\circ} 02^{\prime} \mathrm{E}\right)$. The availability of long-term monitoring data on hydrology (since 1923), water temperature (since 1947), hydrochemistry and biota (since the 1960s) has made the lake a valuable test area to study global change effects on shallow lakes (Nõges \& Nõges, 2012). The water level is unregulated and its absolute range $(3.1 \mathrm{~m})$ exceeds the mean depth of the lake. During ice-free period (234 days), the lake is polymictic stratifying only occasionally in calm days. The median nutrient concentrations (TN $1.45 \mathrm{mg} \mathrm{l}^{-1}$, TP $45 \mu \mathrm{g}^{-1}$ for the period 1994-2018; Fig. 1) fall into the eutrophic range. Throughout the ice-free period, the Secchi depth does not exceed $1 \mathrm{~m}$ (Cremona et al., 2014).

The phytoplankton of Lake Võrtsjärv is dominated by shade and low temperature tolerant slow growing cyanobacteria from the order Oscillatoriales, which share the traits of K-selected phytoplankton species (MacArthur \& Wilson, 1967; Reynolds, 1996). The main dominant until late 1970s, Planktolyngbya limnetica (Lemm.) J. Komárková-Legnerová, was replaced by Limnothrix redekei (Goor) Meffert and L. planktonica (Wołosz.) Meffert, which now form 60 to $90 \%$ of the total phytoplankton biomass. Despite a decline in nutrient loading and concentration in the lake since the 1980s (Fig. 1), the increase of these species has led to elevated total phytoplankton biomass and chlorophyll a concentration (Fig. 2). The proliferation of Limnothrix spp. was related to improved light conditions caused by sharp regional atmospheric stilling and reduced sediment resuspension since 1997 (Janatian et al., 2019). Diatoms form the second abundant group in Võrtsjärv, in which most of the biomass is built up by large filamentous Aulacoseira spp. sharing traits with K-selected species, accompanied by planktonic Fragilaria and benthic or periphytic species from genera Surirella, Gyrosigma, Navicula and Nitschia. Chlorophytes are dominated by small fast growing chlorococcalean or colonial forms such as Scenedesmus, Desmodesmus, Tetraëdron, with traits resembling r-selected species. Finally, chrysophyte and cryptophyte nanoflagellates form omnipresent but low abundance background throughout the year. 


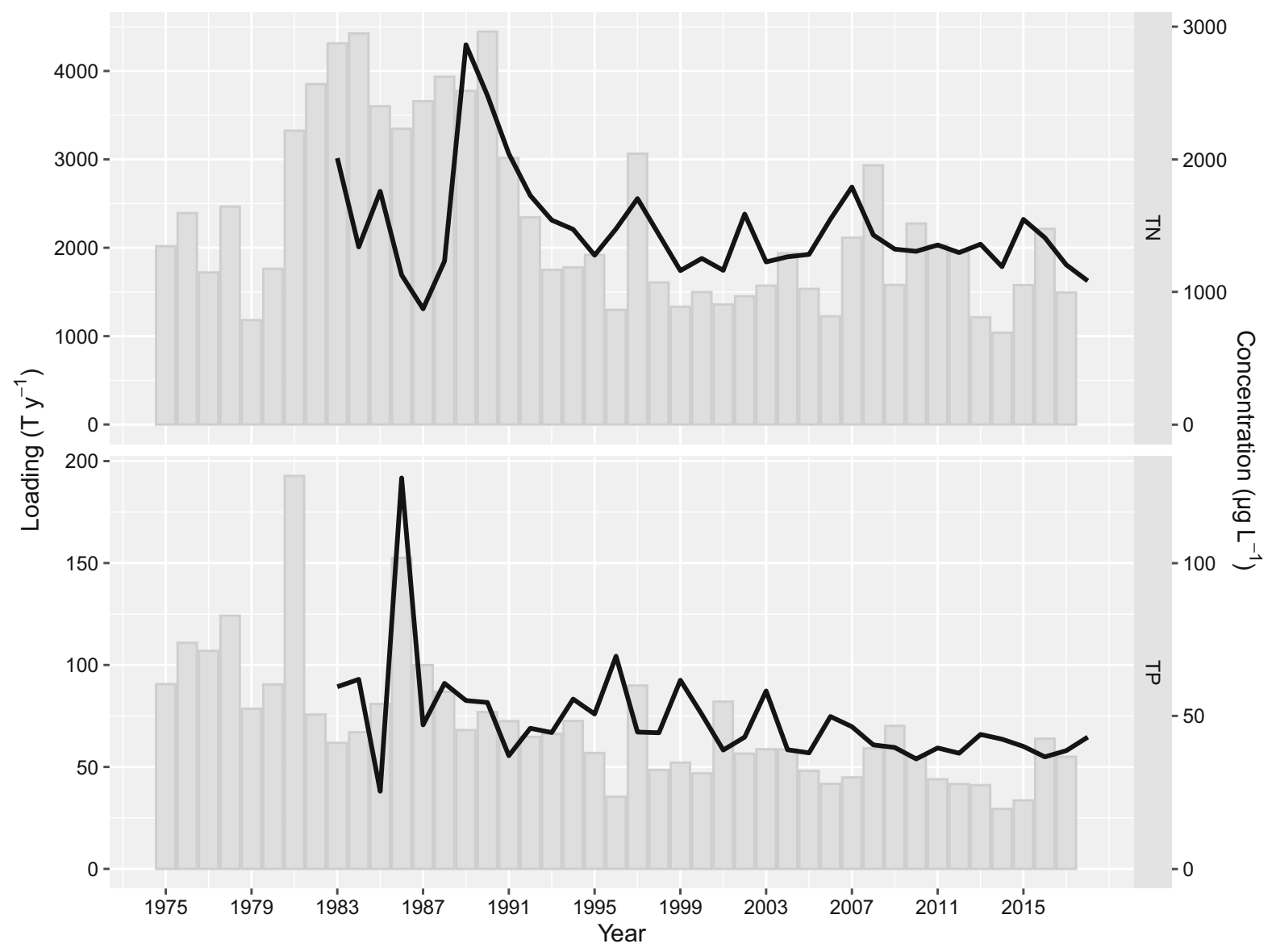

Fig. 1 Total nitrogen $(\mathrm{TN})$ and phosphorus $(\mathrm{TP})$ concentration $\left(\mu \mathrm{g} \mathrm{L}^{-1}\right)$ and loading $\left(\mathrm{T}\right.$ year $\left.{ }^{-1}\right)$ time series in Lake Võrtsjärv

Phytoplankton time series

Phytoplankton abundance and composition were analysed in 503 monthly samples collected from four pelagic stations during the ice-free periods (MayOctober) between 1964 and 2017. Data from the four spatial stations were pooled due to low spatial heterogeneity of phytoplankton in the lake (Nõges \& Tuvikene, 2012). Water samples were taken with a Ruttner sampler either from the surface layer (until 1990) or integrated over the water column (since 1991). A comparison of the surface and bottom samples taken in the earlier period did not show any statistically significant differences in total biomass or biomasses of algal classes (Nõges et al., 2010). Hence, we considered the data from surface and integral samples homogeneous and pooled them for the analysis, as the polymictic shallow lake is well mixed. Until 1994 phytoplankton samples were fixed with $2 \%$ neutralised formalin and counted in Goryajev's counting chamber. Thereafter Lugol's iodine fixative and the inverted microscope technique was used (Lund et al., 1958). The effect of the fixative could be one reason for the observed high stochastic variability among flagellates but had likely no effect on other phytoplankton groups (Hällfors et al., 1979). Intercalibration revealed no significant differences between the counting methods. Biovolume estimates followed the CEN (2004) standard and were converted to wet weight biomass using unit density. For analysis we aggregated the phytoplankton data into total biomass (total B), two orders of cyanobacteria (Oscillatoriales, Nostocales), total cyanobacteria, chloro- crypto- and chrysophytes, and split the diatoms into planktonic and benthic/periphytic forms according to the habitat preferences in Timm (1973).

The 54-year phytoplankton time series has been worked out by just two microscopists, Reet Laugaste 


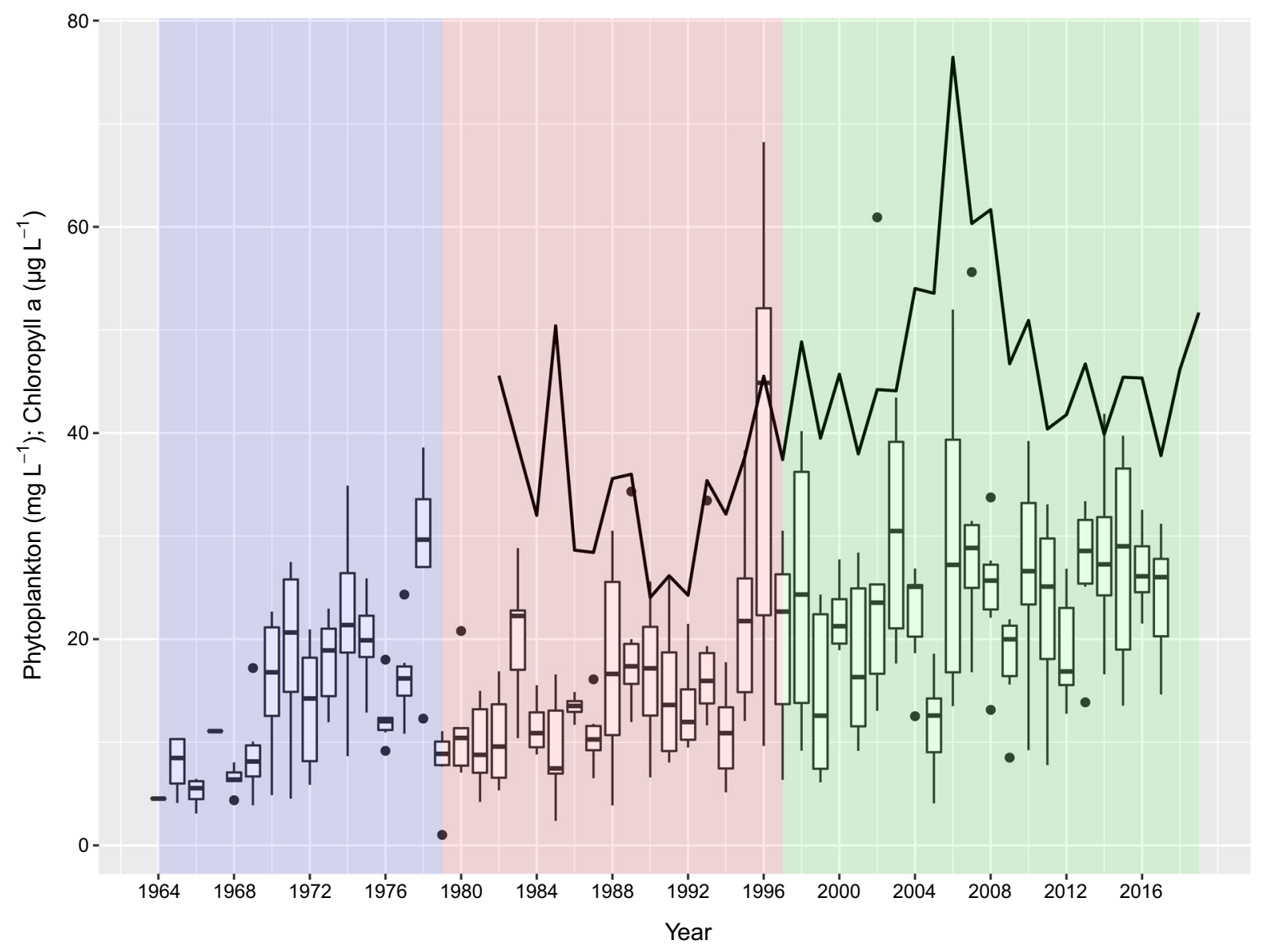

Fig. 2 The time series of phytoplankton wet weight biomass $\left(\mathrm{mg} \mathrm{l}^{-1}\right)$ and chlorophyll a $\left(\mu \mathrm{g}^{-1}\right)$ in Lake Vorrtsjärv. Phytoplankton boxplots show the variation on monthly mean

until the end of 1977, and her trainee Peeter Nõges since then. The transition was thoroughly intercalibrated as it coincided with a regime shift due to a mean water level increase by more than a metre, accompanying with a change in dominant phytoplankton species (Nõges et al., 2010).

\section{Hydrometeorological forcing}

Daily data on wind speed at $10 \mathrm{~m}$ height (U) and incident photosynthetically active radiation $\left(\mathrm{PAR}_{0}\right)$ were measured at the closest to the lake meteorological station (Tõravere, $20 \mathrm{~km}$ ), surface water temperature (SWT), and lake water levels (WL) were received from the Estonian Institute of Hydrology and Meteorology. Mean PAR within the mixed layer $\left(\mathrm{PAR}_{\text {mix }}\right)$ was calculated based on $\mathrm{PAR}_{0}$, Secchi depth values, the superimposed chlorophyll line shows annual means, both calculated for the ice-free period from May to October. The background colours show the three decadal time periods

(SD) and water level. We used the equation for mixed layer irradiance by Riley (1957):

$I_{\text {mix }}=I_{0 *}\left[1-\exp \left(-K_{\mathrm{d}} \times z\right)\right] / K_{\mathrm{d}} \times z$

taking $\mathrm{PAR}_{\text {mix }}$ for $I_{\text {mix }}, \mathrm{PAR}_{0}$ for $I_{0}$, expressing the diffuse attenuation coefficient $\left(K_{\mathrm{d}}\right)$ through its relationship with Secchi depth (SD) in Võrtsjärv (Reinart \& Nõges, 2004):

$K_{\mathrm{d}}=1.95 \mathrm{SD}^{-0.74} \quad\left(R^{2}=0.89 ; P<0.001\right)$

and the depth of the mixed layer $(z)$ by the average depth of the lake $\left(z_{\mathrm{av}}\right)$ calculated from the water level (Nõges \& Järvet, 1995):

$$
\begin{gathered}
z_{\mathrm{av}}=0.741 \times \mathrm{WL}-22.26 \\
\left(R^{2}=0.90 ; P<0.01\right) .
\end{gathered}
$$


SD was measured at each phytoplankton sampling occasion by Secchi disc.

Total nutrients were analysed at the accredited laboratory Tartu Environmental Research Centre Ltd according to the methods described by Grasshoff et al. (1999) and following EVS-EN ISO/IEC 17025:2000 standard.

Hierarchical temporal structure of the time series

In a temperate water body, seasonality inflicts large variation on phytoplankton community structure and hydrometeorological forcing. In addition to temperature and PAR, Lake Võrtsjärv has a natural seasonally fluctuating water level, which by affecting sediment resuspension and light conditions has a major impact on phytoplankton abundance and composition (Nõges \& Järvet, 1995). Interannual variability imposes an additional source of variation (Nõges \& Tuvikene, 2012). Finally, the decadal scale shifts in hydrometeorological variables, like a sudden increase in water level at 1978/1979 (Nõges et al., 2010) and wind stilling in 1996/97 split the 54-year time series into three periods, 1964-1978, 1979-1996, and 1996-2017 (Fig. 3), with differing by phytoplankton community structure (Janatian et al., 2019).

Variance partitioning of phytoplankton and hydrometeorological variables

To analyse which time scales were most influential in explaining variation within the phytoplankton groups and environmental forcing, we used a nested random effects statistical model (lmer function of the lme 4 library in R) to reflect the hierarchical structure of the time series (Zuur, 2009). We adjusted the statistical design used by Thackeray et al. (2013b) in which interannual variation was nested within the decadal scale, and seasonal scale (month) within annual (year). The error term included "residual" variability at finer time scale, variation caused by factors not accounted for, and measurement errors. As we were not interested in the mean value of the variables at any particular time scale, we used the mixed effect model to estimate the separate variance components.

The variance components were estimated as the average variance of the particular time scale averaged over the other time scales. It was impractical to consider interactions between the time scales or among biotic groups. These variance estimates provide the best available approximation on the relative effect sizes of the different time scales on the total variation in phytoplankton community structure and hydrometeorological variables. We created the following formal model structure and applied it separately for each aggregated phytoplankton and hydrometeorological variable:

$m_{d y m}=\beta_{0}+v_{d y m}+v_{y m}+v_{m}+e_{d y m}$

where $m_{d y m}$ is the value of the fixed effect within month $m$, year $y$, and decadal period $d$, and $\beta_{0}$ is the overall mean. Thus, $m_{d y m}$ is the sum of independent nested random effect variance components for seasonal $\left(v_{m}\right)$, interannual $\left(v_{y m}\right)$, and decadal $\left(v_{d v m}\right)$ scales. $e_{d y m}$ is associated with the unexplained variance components and measurement errors. This model with intercept as the fixed effect and time scales as nested random effects was implemented with the lmer function of the lme4 library in R:

$$
\begin{aligned}
& \bmod =\operatorname{lmer}(\text { variable_of_interest } \sim 1 \\
& \quad+(1 \mid \text { decadal } / \text { year } / \text { month }), \text { data }=\text { data_frame }),
\end{aligned}
$$

where variable_of_interest is the respective continuous scale hydrometeorological or aggregated phytoplankton variable, decadal, year, and month are categorical variables defining the hierarchical time structure of the data in data_frame.

Associations between hydrometeorological variables and phytoplankton

In a separate analysis we compared correlations between phytoplankton variables and the four hydrometeorological variables (U, WL, SWT and PARmix) and the total nutrients (TN, TP) to reveal the influential time scales. We compared the correlations with the original non-transformed, and three variants of detrended hydrometeorological variables: (i) after removing the seasonal component, (ii) the long-term and interannual variation, and (iii) both, the seasonal and long-term variation. Detrending was done with generalised additive models ( $\mathrm{gam}$ function of the $\mathrm{mgcv}$ library in R) by regressing the hydrometeorological variables against the smooth terms of (i) the ordinal date (day of year), (ii) year, (iii) ordinal data and year. The residuals of the three models were considered as 

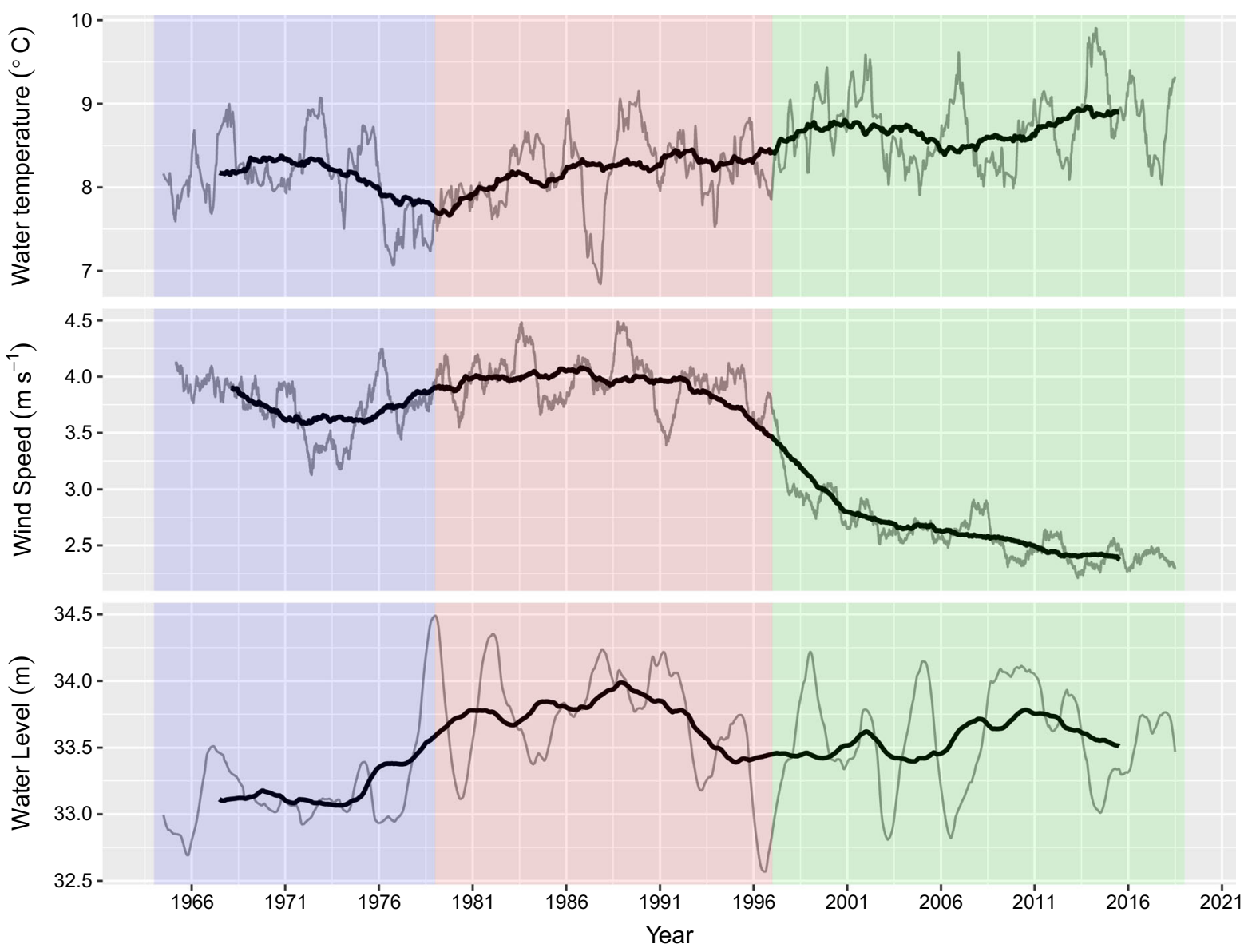

Fig. 3 Time series of water temperature $\left({ }^{\circ} \mathrm{C}\right)$, wind speed $\left(\mathrm{m} \mathrm{s}^{-1}\right)$, and water level $(\mathrm{m})$ over the whole investigation period. The daily time series were deseasonalised with 365 day

the detrended hydrometeorological variables. Correlating the respective detrended variables with phytoplankton emphasises the (i) long-term and interannual scale effect, (ii) seasonal scale effect, and (iii) episodic short scale effect of the hydrometeorological forcing on phytoplankton (O'Farrell et al., 2011; Ho et al., 2019; Janatian et al., 2019; Stockwell et al., 2020).

Finally, as wind data were available at a daily resolution, we were able to test the daily effect of wind forcing. We did this by correlating the biomasses of chlorophytes and diatoms, showing significant correlation with the stochastic component of wind, with instant wind, i.e. the wind on the same day, and lagged wind, i.e. wind at 1-4 days before phytoplankton sampling. moving average (grey line); the black line shows a 7-year moving average. The background colours show the three decadal time periods

\section{Results}

Variance partitioning in variables among different time scales

Variance partitioning demonstrated the significance of all four time scales, but substantial differences between phytoplankton groups (Fig. 4a, Table S1). Expectedly for a temperate lake, the seasonal effect was prominent, particularly among the dominating cyanobacteria and thus also the total biomass (32-45\%). In contrast, the subdominants like the diatoms and chlorophytes, and the background groups like the phytoflagellates, had an increasing proportion of stochastic variation (Fig. 4a). Further, the decadal periods had a strong effect on Oscillatoriales (29\% of total variance). As the latter included the dominant 

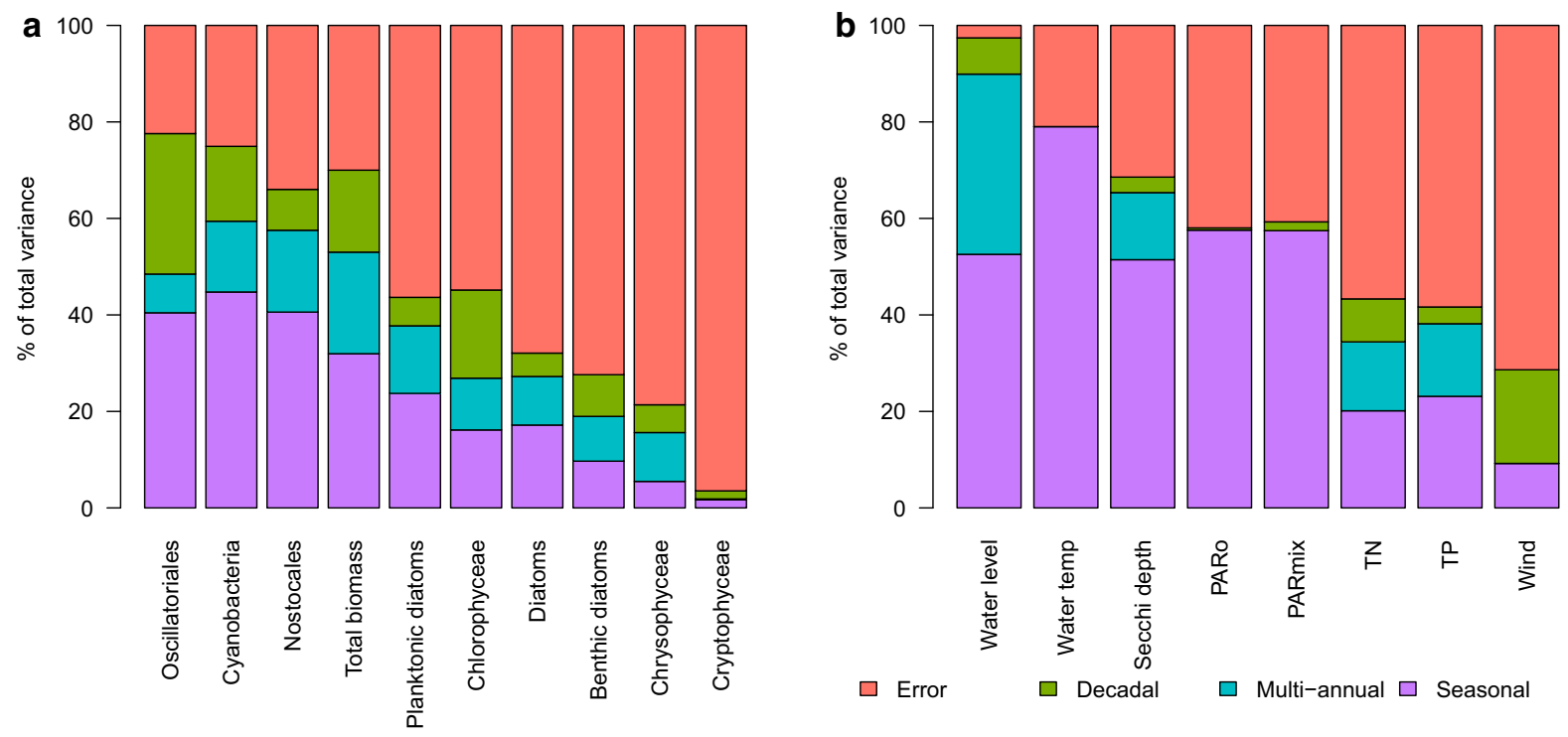

Fig. 4 Variance partitioning among time scales in phytoplankton (a) and explanatory variables (b)

cyanobacteria species in Võrtsjärv, Limnothrix planktonica and $L$. redekei, the high decadal variance was carried over to cyanobacteria and the total biomass. The interannual differences explained $17-21 \%$ of the variance in the total biomass and in the cyanobacteria order Nostocales. The minor groups of phytoflagellates, chrysophytes and cryptophytes showed no variability attributable to decadal periods, cryptophytes also to interannual scale.

The variance partitioning among time scales in explanatory variables showed that water level and wind had a considerable proportion of variance $(8 \%$ and $20 \%$, respectively) attributable to the decadal periods (Fig. 4b). This was expected, since the shifts in the phytoplankton community structure, which defined the decadal periods, were triggered by sudden long-term changes in water level and wind (Janatian et al., 2019). Total nutrients also have a sizable decadal component, a reflecting the long-term downward trend in concentrations. Interannual differences were important sources of variance in water level (37\%) and Secchi depth (14\%) and total nutrients (12-14\%). Except for wind, all environmental variables had a large seasonal variability component $(>45 \%)$. The residual episodic time scale explained $71 \%$ of the total variance in wind, $30-40 \%$ in light nutrient availability, but only $2.6 \%$ in water level.
Hydrometeorological forcing on phytoplankton

Non-transformed wind was weakly positively correlated with chlorophytes, planktonic diatoms, and total diatoms, while correlations with Oscillatoriales, total cyanobacteria and total biomass were not significant. These relationships were confounded by the long-term variation component in wind. The correlations strengthened after removing the long-term and interannual variation in wind speed (Fig. 5). Concomitantly, removing the seasonal component from wind had almost no effect on the correlations, suggesting that these phytoplankton groups are indifferently affected by the wind speed at a seasonal scale, but not on a decadal time scale. Further, the significant positive correlations after removing both, seasonal and long-term components of wind highlighted the importance of short-term episodic time scale.

The flagellates (cryptophytes and chrysophytes) were negatively affected by wind (Fig. 5). Removing seasonal component from the wind slightly strengthened the relationship, suggesting that seasonal variation in wind was a confounding component. In contrast, removing the multi-annual variation in wind turned the negative correlations non-significant, indicating the importance of long-term variation in wind speed in predicting flagellate abundance (Fig. 5).

Increasing water level reduces the average light availability for phytoplankton in the polymictic 


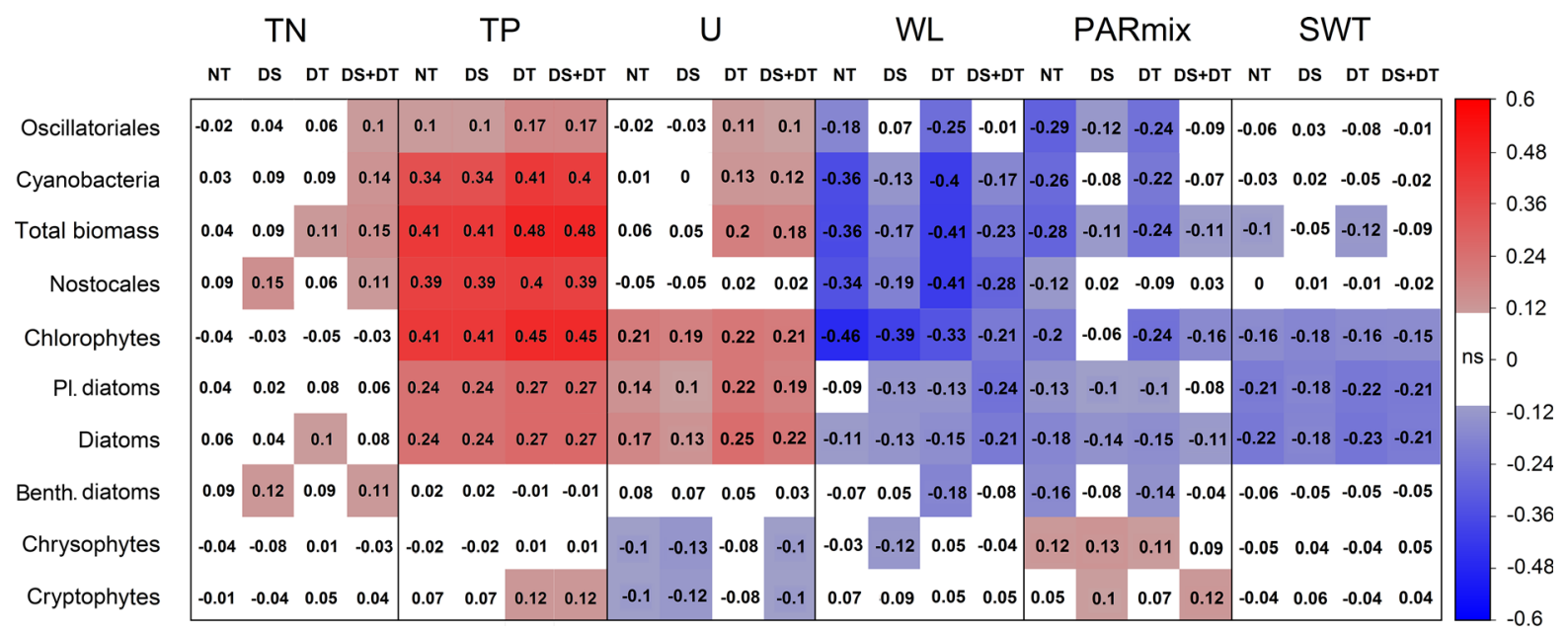

Fig. 5 Correlations of phytoplankton variables with nontransformed and detrended environmental variables. NT nontransformed; $D S$ detrended with respect to season; $D T$ with

brown-water Lake Võrtsjärv (Nõges \& Järvet, 1995), and this negative effect got a correlative support in this study (Fig. 5). Water level acts mostly on total biomass and the cyanobacterial groups on a seasonal time scale, indicated by the weaker correlation with deseasonalised water level. The negative association between water level and chlorophytes is supported by both, seasonal and interannual time scales, while for diatoms seasonality has a confounding effect and negative relationship becomes more apparent after deseasonalizing water level (Fig. 5). The significant negative episodic short-term effect of water level on phytoplankton groups is not easy to interpret, because water level has relatively low episodic variation component (Fig. 4b). Short-term changes in water level are due to seiche waves caused by winds in north-south directions, which could affect phytoplankton, but our data resolution is not suited to test this further. Notably, cryptophytes and chrysophytes are only weakly affected by water level.

PAR in mixed layer was negatively correlated with most of the phytoplankton variables. Analogously with water level, the seasonal component of mixed layer PAR on phytoplankton was dominating over the interannual component. Yet both time scales contributed to the overall negative effect of non-transformed mixed layer PAR.

Chlorophytes and diatoms were the only groups which correlated significantly and negatively with water temperature. Detrending water temperature had respect to year, $D D+D T$ with respect to season and year. Background colour marks significant $(P<0.05)$ correlations. Non-significant (ns) correlations have a white background

no major effect on the correlations, suggesting that the negative relationship was mainly due to the stochastic component of water temperature dynamics. Lack of positive correlation between water temperature and the cyanobacterial groups is due to the insensitivity of the dominant oscillatorian Limnothrix spp. to low temperature. These species can sustain abundant populations even under low light conditions under the ice cover (pers. obs).

TP concentrations reveal a consistent positive relationship with phytoplankton groups at all time scales, except for benthic/periphytic species and chrysophytes, which are known to obtain nutritional resources from the host plant and mixotropy, respectively. Notably, these relationships are remarkably weak with $\mathrm{TN}$, corraborating $\mathrm{P}$ as the potentially limiting nutrient in Lake Võrtsjärv.

The lagged correlation of wind with phytoplankton revealed that diatoms had the strongest positive relationship with instant wind, while chlorophytes correlated best with the wind of the previous day (Fig. 6).

\section{Discussion}

Analysing a 54-year monthly time series, we unravelled the effects of hydrometeorological forcing of lake phytoplankton community variation at different time scales. 


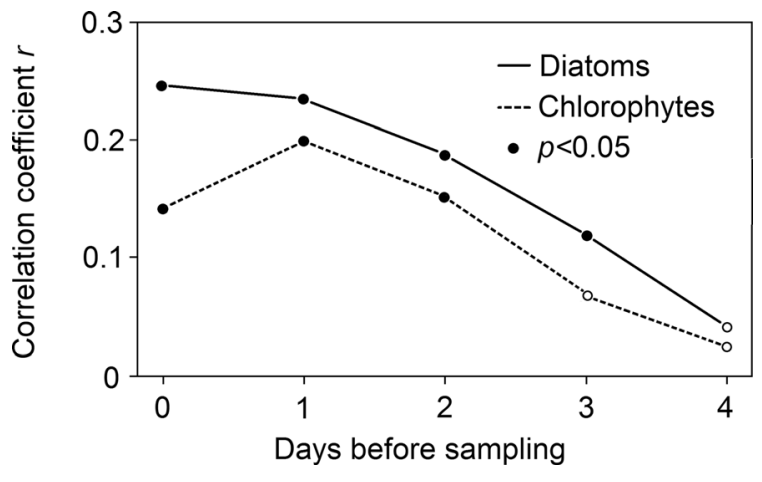

Fig. 6 Relationships of chlorophyte and diatom biomass with wind speed $(U)$ over the period of 0-4 days before phytoplankton sampling

We used two approaches: (1) variance partitioning of phytoplankton and environmental variables with mixed effect linear models with hierarchically nested time scales and (2) comparative correlative analysis by statistically removing the seasonal and long-term interannual variation components from the explanatory hydrometeorological variables. We hypothesised that effects of the driving variables on phytoplankton are manifested proportionally at the same time scales as the variance is partitioned within these explanatory variables.

Hydrometeorological variables act at different time scales

The environmental variables revealed fundamentally different time scales of variance. For most of the variables $60-80 \%$ of variability was at the seasonal time scale. This was expected as the high latitude and boreal temperate climate imposes strong seasonality. As an exception, seasonal time scale had low variability for wind, which was dominated by shortterm stochastic changes. In contrast, water level had almost no short-term stochastic variation component, which was expected as the water level in the lake changes marginally daily or weekly, i.e. within the shortest time scale analysed-the month. Yet both variables, wind and water level, and only those had a considerable share of variance that was attributable to decadal periods. Previously we showed that the two breaking points in phytoplankton community structure (1978-1979 and 1996-1997) matched the ones found at multi-annual scale in water level and wind (Janatian et al., 2019). For water level and Secchi depth also the interannual changes were important, indicating that the time series contains successive multiyear periods of higher or lower water level and Secchi depth.

Divergent response of phytoplankton groups

The stochastic variation component in phytoplankton was generally larger than in the driving variables. Part of this difference could be attributed to the intrinsically higher measurement uncertainty of phytoplankton. The phytoplankton variables could be divided into 3 groups based on the balance between their seasonal and stochastic variability components: (i) the cyanobacteria and the total biomass with the smallest stochastic and largest seasonal component, (ii) chlorophytes and diatoms with medium stochastic variability, and (iii) the two groups of phytoflagellates, chrysophytes and cryptophytes, with $>80 \%$ of stochastic variability.

In Võrtsjärv, the dominating filamentous cyanobacteria are the slow growing, cold and shade tolerant $K$ selected Limnothrix spp., which increase steadily over the growing season. Local grazers tend to avoid Limnothrix filaments (Tõnno et al., 2016), which relaxes the top-down control and effectively decouples them from the grazing food chain. These traits contribute to the well-established seasonal pattern and small stochastic variability. In contrast, the predominant chlorophytes and diatoms in Võrtsjärv are fast growing "opportunistic species" (r-strategists, MacArthur \& Wilson, 1967; Reynolds, 1996), readily utilising pulses of nutrients to rapidly increase their biomass. They are the preferred food for small-bodied crustacean zooplankton in Võrtsjärv from May to September (Agasild et al., 2007; Tõnno et al., 2016). Tighter top-down control contributes to the stochastic component in their variability. The two groups of phytoflagellates constitute the preferred food for a variety of zooplankton, including rotifers (Bogdan \& Gilbert, 1982), cladocerans (Thys et al., 2003), ciliates (Müller \& Schlegel, 1999), and copepod nauplii (Hansen \& Santer, 1995) implying that their variation is largely controlled by strong background grazing pressure. Arauzo and Alvarez Cobelas (1994) studied phytoplankton groups in an eutrophic reservoir at daily to yearly time scales and explained the divergent biomass dynamics along the $r$ - $K$ continuum with resource partitioning, because each strategic group dominated the phytoplankton community at different 
times in the year. Here we show that the strategic phytoplankton groups respond to environmental pressures at widely different time scales. The $r$-strategists tend to have large stochastic (daily) variability, while $K$-strategists are predominantly influenced by longterm, seasonal to decadal scale variation.

The three phytoplankton groups that delineated with the variance partitioning were also distinguished by their relationships with the environmental drivers. The correlations of the dominating Oscillatoriales, cyanobacteria, and total biomass were strongest with the stochastic component of wind and the seasonal components of water level and mixed layer PAR. Accordingly, variation in water level and mixed layer PAR was dominated by the seasonal components, while wind was dominated by stochastic component (Fig. 4b). Unexpectedly we found no significant correlation of the cyanobacterial groups with water temperature, indicating that the cold tolerant Ocillatoriales differ fundamentally from the notorious scum forming and temperature sensitive cyanobacteria in many eutrophic lakes of the world (Wu et al., 2013). Chlorophytes and diatoms (except benthic diatoms) were most responsive showing significant correlations with all of the studied hydrometeorological factors. Compared to other phytoplankton groups, the phytoflagellates had a reversed relationship with wind and mixed layer PAR. Most phytoplankton groups had consistently significant positive correlation with TP at all time scales, which is in good agreement with the measurable variation of total nutrients at all time scales. Although $\mathrm{TN}$ and $\mathrm{TP}$ reveal very similar variance partitioning (Fig. 4b), the variation in phytoplankton groups and TN were apparently uncoupled, re-iterating the prevailing $\mathrm{P}$ limitaiton in the lake.

At the daily scale, diatoms showed an immediate positive response to wind, which can be explained by the turbulent mixing supporting the flotation and resuspension of the cells from the bottom or littoral zone (Huisman et al., 2004). We consider this as a purely mechanical signal, with little, if any physiological response. The biomass of chlorophytes showed a consistent positive response to the wind of the day before the sampling, which cannot be explained by the simple mechanical mixing alone. We speculate that their increase was caused by rapid growth stimulated by improved nutrient availability released from the sediments by resuspension (Holmroos et al., 2009).
Our correlative approach does not reflect direct causal relationships and have to be interpreted with care. E.g. most of the correlations with mixed layer PAR are negative and do not explain causal mechanisms in the light-limited environment. Rather it reflects the good light conditions in early spring when there is still little phytoplankton and water transparency is high, followed by increased shading of the growing phytoplankton populations, leading to adverse light conditions and low mixed layer PAR later during the year. Analogously, the negative correlation with water temperature reflects the long autumn with cool water but high of phytoplankton density. The positive correlation with total phosphorus was expected because the phytoplankton biomass is part of the total nutrient pool. More conspicuous is the consistently weak relationship with $\mathrm{TN}$, pointing to $\mathrm{P}$ as the potentially limiting nutrient, also supported by the scarcity of nitrogen fixing cyanobacteria in Lake Võrtsjärv.

Critical assessment of the statistical methods

The two statistical approaches yielded partly coherent results: both methods indicated the importance of the stochastic component in wind and of the seasonal component in water level and mixed layer PAR. Using the variance partitioning between the time scales appeared as a reliable and useful technique for unravelling the multi-scale time problem, as it yielded easily interpretable quantitative results that matched well with our intuitive understanding of the dynamic behaviour of the different variables. The correlation analysis, although apparently robust, is more disputable as screening for a large number of individual pairwise combinations potentially lead to inflation of the type I error associated with multiple comparisons. We thus present the significant positive or negative associations as plausible hypotheses for future research, rather than as validated cases. Further, spurious correlations and contradictions may emerge if the environmental forcing on phytoplankton poorly corroborates with the proportionality of the variance partitioned within these variables.

For example, variance partitioning showed that only a small part of variability in water level was attributable to stochastic changes, which is fully comprehensible since it is a strongly autocorrelated variable (Lan, 2014). However, the correlations of 
phytoplankton with stochastic component of water level remained significant, which is not easy to interpret. Similarly, variance partitioning showed that $81 \%$ of variability in water temperature was in the seasonal component, indicative of a temperate lake, and the rest $19 \%$ was stochastic. Yet the correlative approach suggested that the stochastic component of water temperature was mostly responsible for the significant negative correlations with phytoplankton. Our analysis showed that detrending the environmental variables could either strengthen or weaken the correlations with phytoplankton. Because the bulk of variability for different environmental variables can be in different temporal components, detrending should be used with care not to throw out the baby with the bathwater. Screening the variables with variance partitioning allows making better informed decisions.

\section{Conclusions}

Using long-term hydrometeorological and phytoplankton data from a large shallow lake, we (1) applied variance partitioning in single time series between time scales from decadal to sub-seasonal and (2) studied the impact of statistically removing the seasonal and interannual effects from explanatory variables on their correlations with phytoplankton groups. We hypothesised that effects of driving variables on phytoplankton are manifested proportionally with the time scales as the variance is partitioned within the explanatory variables.

Variance partitioning revealed the fundamentally different nature of the environmental variables, whereas both analyses distinguished three groups in the phytoplankton variables differing by their position in the food chain and along the continuum of the $r$ $K$ selection: (1) the dominating slow growing filamentous cyanobacteria ( $K$-strategists) determining the dynamics of total cyanobacteria and the total biomass - variables characterised by the lowest stochastic and largest seasonal and decadal component followed by (2) chlorophytes and diatoms with medium stochastic variability and (3) the two groups of phytoflagellates-chrysophytes and cryptophytes-with $>80 \%$ of stochastic variability. The latter two groups belonging to $r$-strategists are subjected to strong grazing pressure in Võrtsjärv.
We found the variance partitioning as a reliable and useful method for studying the multi time scale problem in plankton ecology. It yielded easily interpretable quantitative results that matched with our general understanding of the dynamical behaviour of the different variables. The correlation analysis, however, led to some contradictions that did not fully corroborate with proportionality of variance partitioned in the environmental variables and the time scales of the variables acting on phytoplankton groups. We cautiously blame the spurious character of some correlations, but are confident in the validity and robustness of the variance partitioning results.

We expect this study to introduce variance partitioning as a simple and useful method to get an insight into potential interactions of multiple governing variables controlling plankton dynamics at different time scales and to help reduce the uncertainty in phytoplankton models. Recognising and addressing correct response time scales is fundamental for knowledge-based water management. Understanding the variable character of the driving factors and different response time scales of phytoplankton groups provide for setting feasible targets and avoid spurious expectations. Faithfully implementing short-term measures where the causalities act on decadal scales is a common source of frustration in society.

Acknowledgements This study was funded by MANTEL ITN (Management of climatic extreme events in lakes and reservoirs for the protection of ecosystem services) through European Union's Horizon 2020 research and innovation programme under the Marie Skłodowska-Curie grant agreement No 722518 and by the Estonian Research Council grants (PRG1266 and PRG1167). We would also like to thank Estonian Environment Agency for the long-term data used on this study.

Open Access This article is licensed under a Creative Commons Attribution 4.0 International License, which permits use, sharing, adaptation, distribution and reproduction in any medium or format, as long as you give appropriate credit to the original author(s) and the source, provide a link to the Creative Commons licence, and indicate if changes were made. The images or other third party material in this article are included in the article's Creative Commons licence, unless indicated otherwise in a credit line to the material. If material is not included in the article's Creative Commons licence and your intended use is not permitted by statutory regulation or exceeds the permitted use, you will need to obtain permission directly from the copyright holder. To view a copy of this licence, visit http://creativecommons.org/licenses/by/4.0/. 


\section{References}

Adrian, R., C. M. O’Reilly, H. Zagarese, S. B. Baines, D. O. Hessen, W. Keller, D. M. Livingstone, R. Sommaruga, D. Straile, E. Van Donk, G. A. Weyhenmeyer \& M. Winder, 2009. Lakes as sentinels of climate change. Limnology and Oceanography 54: 2283-2297.

Agasild, H., P. Zingel, I. Tõnno, J. Haberman \& T. Nõges, 2007. Contribution of different zooplankton groups in grazing on phytoplankton in shallow eutrophic Lake Võrtsjärv (Estonia). Hydrobiologia 584: 167-177.

Amin, S. A., L. R. Hmelo, H. M. van Tol, B. P. Durham, L. T. Carlson, K. R. Heal, R. L. Morales, C. T. Berthiaume, M. S. Parker, B. Djunaedi, A. E. Ingalls, M. R. Parsek, M. A. Moran \& E. V. Armbrust, 2015. Interaction and signalling between a cosmopolitan phytoplankton and associated bacteria. Nature 522: 98-101.

Arauzo, M. \& M. Alvarez Cobelas, 1994. Phytoplankton strategies and time scales in a eutrophic reservoir. Hydrobiologia 291: 1-9.

Benndorf, Ju, W. Boing, J. Koop \& I. Neubauer, 2002. Topdown control of phytoplankton: the role of time scale, lake depth and trophic state. Freshwater Biology 47: 2282-2295.

Bogdan, K. G. \& J. J. Gilbert, 1982. Seasonal patterns of feeding by natural populations of Keratella, Polyarthra, and Bosmina: clearance rates, selectivities, and contributions to community grazing1: Rotifer and Bosmina grazing. Limnology and Oceanography 27: 918-934.

Carrick, H. J., F. J. Aldridge \& C. L. Schelske, 1993. Wind influences phytoplankton biomass and composition in a shallow, productive lake. Limnology and Oceanography 38: 1179-1192.

CEN, 2004. Water quality-Guidance standard for the routine analysis of phytoplankton abundance and composition using inverted microscopy (Utermöhl technique) CEN TC 230/WG 2/TG 3/N83.

Cremona, F., T. Kõiv, V. Kisand, A. Laas, P. Zingel, H. Agasild, T. Feldmann, A. Järvalt, P. Nõges \& T. Nõges, 2014. From bacteria to piscivorous fish: estimates of whole-lake and component-specific metabolism with an ecosystem approach. PLoS ONE 9:

Cuypers, Y., B. Vinçon-Leite, A. Groleau, B. Tassin \& J.-F. Humbert, 2011. Impact of internal waves on the spatial distribution of Planktothrix rubescens (cyanobacteria) in an alpine lake. The ISME Journal 5: 580-589.

Durham, W. M., E. Climent, M. Barry, F. De Lillo, G. Boffetta, M. Cencini \& R. Stocker, 2013. Turbulence drives microscale patches of motile phytoplankton. Nature Communications 4: 2148.

Edwards, K. F., E. Litchman \& C. A. Klausmeier, 2013. Functional traits explain phytoplankton responses to environmental gradients across lakes of the United States. Ecology 94: 1626-1635.

Eiler, A., F. Heinrich \& S. Bertilsson, 2012. Coherent dynamics and association networks among lake bacterioplankton taxa. The ISME Journal 6: 330-342.

Field, C. B., 1998. Primary production of the biosphere: integrating terrestrial and oceanic components. Science 281: $237-240$.
Fraisse, S., M. Bormans \& Y. Lagadeuc, 2015. Turbulence effects on phytoplankton morphofunctional traits selection: functional traits selected by turbulence. Limnology and Oceanography 60: 872-884.

Francis, R. C., S. R. Hare, A. B. Hollowed \& W. S. Wooster, 1998. Effects of interdecadal climate variability on the oceanic ecosystems of the NE Pacific. Fisheries Oceanography 7: 1-21.

Gerten, D. \& R. Adrian, 2002. Effects of climate warming, North Atlantic Oscillation, and El Niño-Southern Oscillation on thermal conditions and plankton dynamics in northern hemispheric lakes. The Scientific World Journal 2: 586-606.

Grasshoff, K., K. Kremling, \& M. Ehrhardt (eds), 1999. Methods of Seawater Analysis. Wiley, Weinheim.

Hällfors, G., T. Melvasalo, Å. Niemi \& H. Viljamaa, 1979. Effect of different fixatives and preservatives on phytoplankton counts. Publications of the Water Research Institute 34: 25-34.

Hansen, A.-M. \& B. Santer, 1995. The influence of food resources on the development, survival and reproduction of the two cyclopoid copepods: Cyclops vicinus and Mesocyclops leuckarti. Journal of Plankton Research 17: 631-646.

Hansson, L.-A., A. Nicolle, W. Granéli, P. Hallgren, E. Kritzberg, A. Persson, J. Björk, P. A. Nilsson \& C. Brönmark, 2012. Food-chain length alters community responses to global change in aquatic systems. Nature Climate Change 3: 228-233.

Ho, J. C., A. M. Michalak \& N. Pahlevan, 2019. Widespread global increase in intense lake phytoplankton blooms since the 1980s. Nature 574: 667-670.

Holmroos, H., J. Niemistö, K. Weckström \& J. Horppila, 2009. Seasonal variation of resuspension-mediated aerobic release of phosphorus. Boreal Environment Research 14: 937-946.

Huisman, J., J. Sharples, J. M. Stroom, P. M. Visser, W. E. A. Kardinaal, J. M. H. Verspagen \& B. Sommeijer, 2004. Changes in turbulent mixing shift competition for light between phytoplankton species. Ecology 85: 2960-2970.

Janatian, N., K. Olli, F. Cremona, A. Laas \& P. Nõges, 2019. Atmospheric stilling offsets the benefits from reduced nutrient loading in a large shallow lake. Limnology and Oceanography 65: 717-731.

Lan, Y., 2014. Forecasting performance of support vector machine for the Poyang Lake's water level. Water Science and Technology 70: 1488-1495.

Li, W. K. W., M. R. Lewis \& W. G. Harrison, 2010. Multiscalarity of the nutrient-chlorophyll relationship in coastal phytoplankton. Estuaries and Coasts 33: 440-447.

Lund, J. W. G., C. Kipling \& E. D. Le Cren, 1958. The inverted microscope method of estimating algal numbers and the statistical basis of estimations by counting. Hydrobiologia 11: 143-170.

MacArthur, R. \& E. Wilson, 1967. The theory of island biogeography. Princeton University Press, Princeton.

Moss, B., S. Kosten, M. Meerhoff, R. W. Battarbee, E. Jeppesen, N. Mazzeo, K. Havens, G. Lacerot, Z. Liu, L. D. Meester, H. Paerl \& M. Scheffer, 2011. Allied attack: climate change and eutrophication. Inland Waters 1: 101-105. 
Müller, H. \& A. Schlegel, 1999. Responses of three freshwater planktonic ciliates with different feeding modes to cryptophyte and diatom prey. Aquatic Microbial Ecology 17: 49-60.

Nõges, P. \& A. Järvet, 1995. Water level control over light conditions in shallow lakes. Report Series in Geophysics, University of Helsinki 32: 81-92.

Nõges, P. \& T. Nõges, 1998. The effect of fluctuating water level on the ecosystem of Lake Võrtsjärv, Central Estonia. Proceedings of the Estonian Academy of Sciences, Biology and Ecology 47: 98-113.

Nõges, P. \& T. Nõges, 2012. Võrtsjärv Lake in Estonia. In Bengtsson, L., R. W. Herschy \& R. W. Fairbridge (eds), Encyclopedia of Lakes and Reservoirs. Springer, Dordrecht: 850-861.

Nõges, P. \& L. Tuvikene, 2012. Spatial and annual variability of environmental and phytoplankton indicators in Lake Võrtsjärv: implications for water quality monitoring. Estonian Journal of Ecology 61: 227.

Nõges, P. \& T. Nõges, 2014. Weak trends in ice phenology of Estonian large lakes despite significant warming trends. Hydrobiologia 731: 5-18.

Nõges, T., P. Nõges \& R. Laugaste, 2003. Water level as the mediator between climate change and phytoplankton composition in a large shallow temperate lake. Hydrobiologia 506-509: 257-263.

Nõges, P., U. Mischke, R. Laugaste \& A. G. Solimini, 2010. Analysis of changes over 44 years in the phytoplankton of Lake Võrtsjärv (Estonia): the effect of nutrients, climate and the investigator on phytoplankton-based water quality indices. Hydrobiologia 646: 33-48.

O'Farrell, I., I. Izaguirre, G. Chaparro, F. Unrein, R. Sinistro, H. Pizarro, P. Rodríguez, P. de Tezanos Pinto, R. Lombardo \& G. Tell, 2011. Water level as the main driver of the alternation between a free-floating plant and a phytoplankton dominated state: a long-term study in a floodplain lake. Aquatic Sciences 73: 275-287.

Pall, P., S. Vilbaste, T. Kõiv, A. Kõrs, K. Käiro, A. Laas, P. Nõges, T. Nõges, K. Piirsoo, L. Toomsalu \& M. Viik, 2011. Fluxes of carbon and nutrients through the inflows and outflow of Lake Võrtsjärv. Estonia. Estonian Journal of Ecology 60: 39.

Pannard, A., M. Bormans \& Y. Lagadeuc, 2007. Short-term variability in physical forcing in temperate reservoirs: effects on phytoplankton dynamics and sedimentary fluxes. Freshwater Biology 52: 12-27.

Pannard, A., M. Bormans \& Y. Lagadeuc, 2008. Phytoplankton species turnover controlled by physical forcing at different time scales. Canadian Journal of Fisheries and Aquatic Sciences 65: 47-60.

Posch, T., O. Köster, M. M. Salcher \& J. Pernthaler, 2012. Harmful filamentous cyanobacteria favoured by reduced water turnover with lake warming. Nature Climate Change 2: 809-813.

Reinart, A. \& P. Nõges, 2004. Light condition in lake Võrtsjärv. In Haberman, J., P. Ervin \& R. Anto (eds), Võrtsjärv. Estonian Encyclopaedia Publishers, Tallinn: 141-149.

Reynolds, C. S., 1996. The plant life of the pelagic. SIL Proceedings 1922-2010(26): 97-113.

Riley, G. A., 1957. Phytoplankton of the North Central Sargasso Sea, 1950-52. Limnology and Oceanography 2: 252-270.
Scheffer, M. \& E. H. van Nes, 2007. Shallow lakes theory revisited: various alternative regimes driven by climate, nutrients, depth and lake size. Hydrobiologia 584: 455-466.

Shatwell, T., R. Adrian \& G. Kirillin, 2016. Planktonic events may cause polymictic-dimictic regime shifts in temperate lakes. Scientific Reports 6: 24361.

Sommer, U., R. Adrian, L. De Senerpont Domis, J. J. Elser, U. Gaedke, B. Ibelings, E. Jeppesen, M. Lürling, J. C. Molinero, W. M. Mooij, E. van Donk \& M. Winder, 2012. Beyond the Plankton Ecology Group (PEG) model: mechanisms driving plankton succession. Annual Review of Ecology, Evolution, and Systematics 43: 429-448.

Stockwell, J. D., J. P. Doubek, R. Adrian, O. Anneville, C. C. Carey, L. Carvalho, L. N. De Senerpont Domis, G. Dur, M. A. Frassl, H. Grossart, B. W. Ibelings, M. J. Lajeunesse, A. M. Lewandowska, M. E. Llames, S. S. Matsuzaki, E. R. Nodine, P. Nõges, V. P. Patil, F. Pomati, K. Rinke, L. G. Rudstam, J. A. Rusak, N. Salmaso, C. T. Seltmann, D. Straile, S. J. Thackeray, W. Thiery, P. Urrutia-Cordero, P. Venail, P. Verburg, R. I. Woolway, T. Zohary, M. R. Andersen, R. Bhattacharya, J. Hejzlar, N. Janatian, A. T. N. K. Kpodonu, T. J. Williamson \& H. L. Wilson, 2020. Storm impacts on phytoplankton community dynamics in lakes. Global Change Biology 26: 2756-2784.

Thackeray, S. J., P. A. Henrys, H. Feuchtmayr, I. D. Jones, S. C. Maberly \& I. J. Winfield, 2013a. Food web de-synchronization in England's largest lake: an assessment based on multiple phenological metrics. Global Change Biology 19: 3568-3580.

Thackeray, S. J., P. Nõges, M. J. Dunbar, B. J. Dudley, B. Skjelbred, G. Morabito, L. Carvalho, G. Phillips, U. Mischke, J. Catalan, C. de Hoyos, C. Laplace, M. Austoni, B. M. Padedda, K. Maileht, A. Pasztaleniec, M. Järvinen, A. L. Solheim \& R. T. Clarke, 2013b. Quantifying uncertainties in biologically-based water quality assessment: a pan-European analysis of lake phytoplankton community metrics. Ecological Indicators 29: 34-47.

Thomas, M. K., S. Fontana, M. Reyes, M. Kehoe \& F. Pomati, 2018. The predictability of a lake phytoplankton community, over time-scales of hours to years. Ecology Letters 21: 619-628.

Thys, I., L. Bruno \& D. Jean-Pierre, 2003. Seasonal shifts in phytoplankton ingestion by Daphnia galeata, assessed by analysis of marker pigments. Journal of Plankton Research 25: $1471-1484$.

Timm, T., 1973. Võrtsjärv. Valgus, Tallinn.

Tõnno, I., H. Agasild, T. Kõiv, R. Freiberg, P. Nõges \& T. Nõges, 2016. Algal diet of small-bodied crustacean zooplankton in a cyanobacteria-dominated eutrophic lake. PLOS ONE 11:

Vasconcelos, F. R., S. Diehl, P. Rodríguez, P. Hedström, J. Karlsson \& P. Byström, 2019. Bottom-up and top-down effects of browning and warming on shallow lake food webs. Global Change Biology 25: 504-521.

Wagner, H., A. Fanesi \& C. Wilhelm, 2016. Title: Freshwater phytoplankton responses to global warming. Journal of Plant Physiology 203: 127-134.

Winder, M. \& D. E. Schindler, 2004. Climatic effects on the phenology of lake processes. Global Change Biology 10: 1844-1856. 
Wu, T., B. Qin, G. Zhu, L. Luo, Y. Ding \& G. Bian, 2013. Dynamics of cyanobacterial bloom formation during shortterm hydrodynamic fluctuation in a large shallow, eutrophic, and wind-exposed Lake Taihu, China. Environmental Science and Pollution Research 20: 8546-8556.

Zuur, A. F. (ed.), 2009. Mixed Effects Models and Extensions in Ecology with R. Springer, New York.
Publisher's Note Springer Nature remains neutral with regard to jurisdictional claims in published maps and institutional affiliations. 